\title{
BIM-Integration of solar thermal systems in early housing design
}

\section{Integración BIM de sistemas solares térmicos en diseño inicial de viviendas}

\author{
Alejandro Bonilla Castro (Main and Corresponding Author) \\ Depto. de Diseño y Teoría de la Arquitectura - Universidad del Bío Bío (Chile) \\ Av. Collao 1202, Concepción, Chile. \\ alejandro.bonilla9@gmail.com
}

\section{Rodrigo García Alvarado}

Depto. de Diseño y Teoría de la Arquitectura - Universidad del Bío Bío (Chile)

Av. Collao 1202, Concepción, Chile.

rgarcia@ubiobio.cl

\author{
Manuscript Code: 809 \\ Date of Acceptance/Reception: 04.08.2017/08.09.16 \\ DOI: $10.7764 /$ RDLC.16.2.323
}

\begin{abstract}
This paper sets a methodology to integrate solar thermal systems in BIM-software for the early architectural design of single houses in Concepción, Chile, using parametric families, programming in Dynamo, energy calculation with LadyBug and piping design in MEP. The results obtained allowed to select products, insert and adapts automatically the parametric designs into the model, as well as to identify changes in the type and number of solar components when the solar orientation of the house is modified. It can be applied to more products, different geographic locations and designs of houses or buildings with a similar methodology.
\end{abstract}

Key words: Solar Thermal System, Parametric analysis, architectural integration, BIM.

\begin{abstract}
Resumen
Este trabajo desarrolla una metodología para integrar Sistemas Solares Térmicos (SST) en software de diseño BIM durante etapas iniciales del diseño arquitectónico de viviendas unifamiliares en la ciudad de Concepción, Chile; mediante el uso de familias paramétricas, programación algorítmica en Dynamo, análisis medioambiental con Ladybug y diseño de sistema de tuberías en MEP. Obteniendo como resultado un método de diseño integrado que permite seleccionar productos solares y adaptarlos automáticamente en el diseño de la vivienda, identificando el tipo y cantidad de componentes a utilizar en función al ángulo de inclinación del techo y orientación; existiendo la posibilidad de aplicarlo con más productos, diferentes ubicaciones geográficas y diseños de viviendas o edificios con una metodología similar.
\end{abstract}

Palabras clave: Sistema Solar Térmico, Análisis Paramétrico, Integración Arquitectónica, BIM.

Introduction

Solar collection technologies integrated into buildings help to reduce fuel consumptions and greenhouse gas emissions significantly (Yan et al., 2013), but it is required to be incorporated in early stages of building design. The "IEA SHC Task 41 document: Solar energy and Architecture", establishes that the solar energy systems do not have as much demand to be integrated into the buildings for the following reasons: economic factors associated with the investment and maintenance costs, lack of technical knowledge from architects and manufacturers, and control of the architectural aesthetic in the envelope of the building. This last factors derived from the lack of tools that can evaluate and illustrate the influence of several applications of solar energy in a beginning of building design that allows doing changes of the project (Wall, Windeleff, \& Lien, 2008).

The methods that describe and recommend implementing solar thermal systems (STS), photovoltaic and hybrid in buildings, lack tasks, like to identify surfaces with higher solar potential related to morphology, function and structure of a building in the early stages of design; to match the collection of solar radiation with the performance of each technology to meet needs as domestic hot water, heating and electricity, as well to develop the detail of the installation in the building design and architectural visualization of the system (Horvat \& Dubois, 2012).

To address the integration of performance analysis in the building design process, some studies have been done with parametric tools (Rahmani et al., 2015) (Jakubiec \& Reinhart, 2011). These studies try to enable designers to explore various formal options and access energy assessment quickly. The common goal of all of these studies is to create a programming to relate the geometry of the building in the early design phase with performance analysis. Most of these tools are created with Rhinoceros ${ }^{\circledR}$ (Rhino), a 3D modeling program, with visual programming editor, Grasshopper $^{\circledast}$, which facilitates parametric design, linked to energy calculation engines. Nevertheless, these platforms 
do not have access to all building elements and workflow available in BIM (Building Information Modeling) systems, like Revit, Archicad and Nemetschek, that are increasingly used in the construction industry to develop the design and manage design delivery process (Rahmani et al., 2015).

During the design process, the performance of a scheme might be optimized by a sequence of analysis and feedback. BIM consolidates this iteration, since the intelligent model serves as a common, continuously up-to date database that is steadily refined until the desired objectives are met (Lobos, Wandersleben, \& Castillo, 2014) (Liu et al., 2015).

The ideal and automated integration of multi-criteria design evaluation with BIM is not fully implemented yet. Instead of automatically generating a Building Energy Model (BEM model), manually re-entering of architectural and technical information into a static calculation or dynamic simulation software is common practice: a highly inefficient working method, prone to errors (Senave \& Boeykens, 2015).

By such reason, this article sets a methodology to integrate solar systems in a BIM-software, with the example of a real-estate house in Concepción, Chile. Through an experimental research to identify and characterize solar thermal systems (STS) available in the zone and typical single-family houses of real-estate complexes, to define their characteristics and linked them to the BIM software using an algorithmic programming with Dynamo, piping layout with MEP, energy calculation with LadyBug, as well as economic assessment and architectural visualization.

The study obtained an integrated design method that allowed to select products, insert and adapts automatically into the parametric building model. And also, to verify their adaptability to each design of houses. Besides, the parametric analysis allowed identifying changes in the type and number of solar components when the solar orientation of the house is modified

This integration of the BIM concept into the design stage can and be used to select the best green building designs and reduce the need for later design modifications that require extra time and cost. Efforts to prevent adverse environmental impacts and to minimize energy costs are beginning to show beneficial effects in terms of more efficient and sustainable building designs, improved building performance, and minimization of environmental risks (Shoubi et al. 2015)

First, a review of solar thermal systems (STS) most used in the zone was carried out, to define the shape and technical features of products proper to be integrated into roofs of single-family houses in Concepcion. Secondly, a selection of two cases of real-estate models was done, that have different roof inclination $\left(40^{\circ}\right.$ and $\left.27^{\circ}\right)$ and built surface, but a similar amount of rooms: 3 bedrooms, 2 bathrooms, family room, kitchen and living-dining room. Third, it was applied the parametric design of all components of STS in the digital model of the houses created in Revit software. Algorithmic programming generated with language Dynamo and environmental analysis through Ladybug enabled the calculation of the panels and tanks most suitable to the orientation and roof configuration of each house. Linked to an Excel table to determine the collection solar area and the accumulator capacity necessary to supply the demand of domestic hot water, according to national law 20.365 that provide a state subsidy for these installations.

The procedure carried out allowed to select products, insert and adapts automatically the parametric designs into the model. And also, to integrate them into a piping layout with MEP utilities of Revit software, optimizing the routing and connections between the fittings and domestic equipment; in order to verify their adaptability to each housing design.

\section{Characterization of solar thermal systems (STS) and housing models}

It was determined that the STS of forced type is the most suitable for architectural integration of houses, due it allows inserting solar collector on the roof independently to the other elements of the system. These systems have collectors of different types and dimensions. The most commonly used are plane collectors, which have $2.0 \mathrm{~m}^{2}$ or $2.4 \mathrm{~m}^{2}$ of the catchment area, and the Heat pipe, which an area of catchment between $2.6 \mathrm{~m}^{2}$ and $4.4 \mathrm{~m}^{2}$ (Table 1). Both of them can have accumulators of DHW (Domestic Hot Water) type glazed with coil and capacities between $200 \mathrm{I}$ and $500 \mathrm{I}$. This information allowed creating in Revit software the parametric family of each element with the geometry and technological features for the calculation of the STS, with the possibility to generate various options of design in function to the demand of ACS and features of the housing. 
Table 1. Characteristics of solar thermal systems available in the city of Concepción. Source: the author.

\begin{tabular}{|c|c|c|c|c|c|c|}
\hline \multicolumn{2}{|c|}{ Technical specifications } & \multicolumn{3}{|c|}{ Heat pipe collectors } & \multicolumn{2}{|c|}{ Plane collectors } \\
\hline & & & & & Wunder CLS & Wunder CLS \\
\hline Characteristics & Unit & Zelios VDF 15 & Zelios VDF 20 & ILHC - 5830 & 2510 & 2108 \\
\hline Amount heat pipe & & 15 & 20 & 30 & & \\
\hline Weight & $\mathrm{Kg}$ & 51 & 68 & 92.6 & 44 & 37.2 \\
\hline Size & $\mathrm{mm}$ & $1380 * 1910 * 178$ & $1840 * 1910 * 178$ & $1894 * 2310 * 135$ & $1988 * 1218 * 90$ & $1988 * 1041 * 90$ \\
\hline Working pressure & bar & 6 & 6 & & 10 & 10 \\
\hline Liquid content & 1 & 4.3 & 5.7 & & & \\
\hline Absorption & $\%$ & 95 & 95 & & 97 & 97 \\
\hline Emissivity & $\%$ & 5 & 5 & & 3 & 3 \\
\hline Total surface & $\mathrm{m}^{2}$ & 2.63 & 3.51 & 4.37 & 2.42 & 2.07 \\
\hline Opening surface & $\mathrm{m}^{2}$ & 1.58 & 2.12 & & 2.24 & 1.92 \\
\hline Absorption surface & $\mathrm{m}^{2}$ & 1.51 & 2.01 & 2.4 & 2.23 & 1.9 \\
\hline$h_{0}$ & & $0.816^{*}$ & $0.821^{*}$ & & & \\
\hline $\mathrm{K}, \mathrm{w} /\left(\mathrm{m}^{2} \mathrm{k}\right)$ & & $2.735^{*}$ & $2.824^{*}$ & 2.46 & 3.514 & 3.514 \\
\hline $\mathrm{K}_{2} \mathrm{w} /\left(\mathrm{m}^{2} \mathrm{k}^{2}\right)$ & & $0.0074 *$ & $0.0047^{*}$ & 0.0007 & 0.008 & 0.008 \\
\hline $\begin{array}{l}\text { Stagnation } \\
\text { temperature }\end{array}$ & ${ }^{\circ} \mathrm{C}$ & 206 & 206 & 250 & 211 & 211 \\
\hline Glass material & & & & Borosilicato 3.3 & $\begin{array}{r}\text { Tempered } \\
\text { glass }\end{array}$ & Tempered glass \\
\hline Transmittance glass & $\%$ & & & & 91 & 91 \\
\hline Thickness glass & $\mathrm{mm}$ & & & & 4 & 4 \\
\hline Insulating & & & & & Mineral wool & Mineral wool \\
\hline $\begin{array}{l}\text { Thermal } \\
\text { conductivity }\end{array}$ & $w(m k)$ & & & & 0.037 & 0.037 \\
\hline $\begin{array}{l}\text { Optical } \\
\quad \text { performance }\end{array}$ & $\%$ & & & 72.5 & 76.3 & 76.3 \\
\hline
\end{tabular}

To identify current housing models built in the city of Concepcion, it is taken as reference the county archive of building projects from 2006, where are identified the bigger real estate complexes with 2139 houses built. This coverage provides a statistically $95 \%$ confidence interval with respect to all homes built during the period, thus providing an accurate representation of the current residential construction (Zalamea \& García, 2014).

The nine-complex real estate reviewed contain 33 models different from single family houses, detached or semidetached. The five types of houses that present greater number of units according to the total sample, shows a number of houses between 110 to 339 units (Figure 1). 


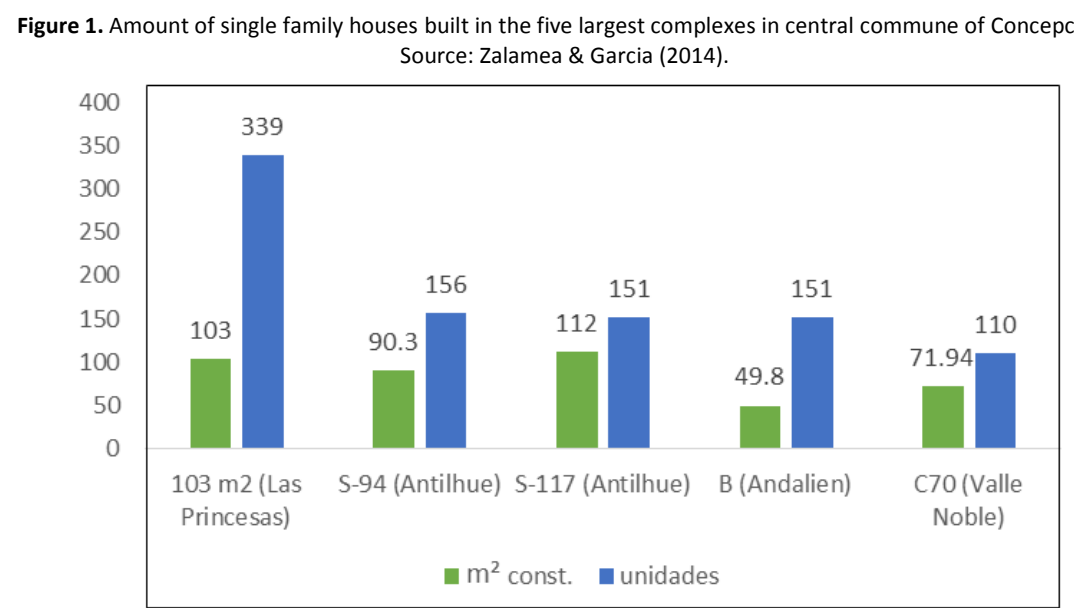

Based on this data, the two models with a greater number of units built the last decade in the central commune of Concepción were selected: a house of $103 \mathrm{~m}^{2}$ located in "Las Princesas" complex, and a house belonging to the complex Antilhue (S-94). The selected models are common designs and allows to have detailed building information: type of roof, roof inclination, construction area, and other parameters specified in Table 2.

\begin{tabular}{lccc}
\multicolumn{4}{c}{ Table 2. Characteristics of the two housing type. Source: the author. } \\
\hline Characteristics & Unit & Type A & Type B \\
\hline Name & & House S-94 & House $103 \mathrm{~m}^{2}$ \\
Complex & $\mathrm{m}^{2}$ & Antilhue & Las Princesas \\
Built Surface on the first floor & $\mathrm{m}^{2}$ & 90.25 & 60.53 \\
Total surface & & 2 & 103 \\
Number of Floors & $\mathrm{m}^{2}$ & 69.21 & 2 \\
Horizontal roof surface & $\mathrm{m}^{2}$ & 94.61 & 77.74 \\
Inclined roof surface & & 4 & 91.76 \\
Amount of Wings & $\mathrm{m}^{2}$ & 52.96 & 6 \\
Surface of biggest roof wing & degree & 40 & 43.78 \\
Slope of biggest roof wing & degree & 30.93 & 26.71 \\
Slope of second biggest roof wing & unit & 3 & 22.43 \\
Number of Rooms & unit & 2 & 3 \\
Number of Bathrooms & & & 2 \\
\hline
\end{tabular}

The roofs of the selected houses have an inclination of $40^{\circ}$ and $26.71^{\circ}$ (Figure 2), which coincides with the common slopes of approximately 1,000 cases studied by Zalamea and Garcia (2014) of a total of 2139 units (47\% of the sample). Both cases present different built surface and layout, however, they have the same amount of rooms: 3 bedrooms, 2 bathrooms, family room, kitchen and living-dining room. This condition allows designing the STS with a demand for domestic hot water equal to two cases, with opportunities to explore variations on the system by the differences in roof slope and house orientation.

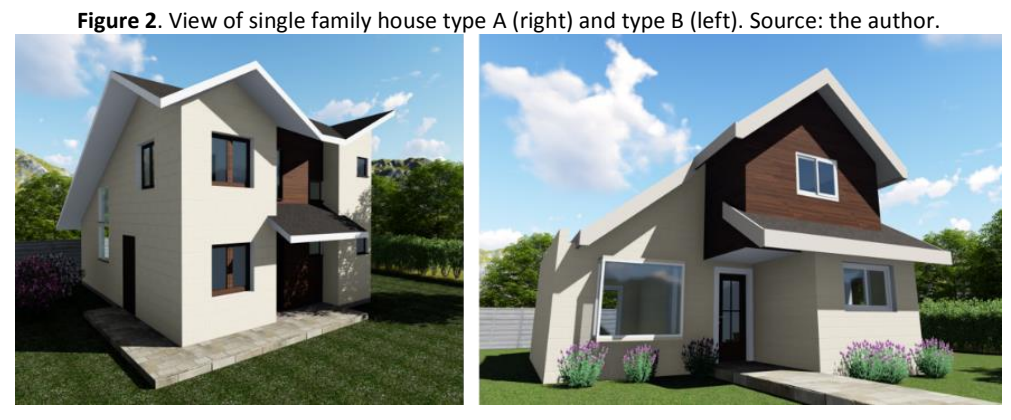




\section{BIM - Parametric families}

The representation of the Solar Thermal System (STS) like parametric families include a piping system on Revit MEP by placing mechanical components in the house model, assigning them to a supply or return course. Subsequently, with the use of design tools it can determine the best routing for the pipes that connect the system components.

The products identified compound each family associated with the category of mechanical equipment. This category includes different types of components, each one has a graphic representation associated and an identical set of data, called family parameters. The table 3 shows the family parameters to be applied in the process of STS design, with properties of each one, to select which best suits to the requirements of the house.

\section{Link the STS in the parametric design of a house}

The parametric family of STS is placed in the house design made in Revit (case of study A) to review its integration, establishing geometric relationships between components. This way enhances the possibility of examining variants without the need to do all representation work again.

The use of parametric families of each of its components, especially the roof, allows it to control the location of entities in the model, and to obtain data of geometry and orientation necessary for sizing and integration of the STS.

Table 3. Parameters of BIM families. Source: the author.

\begin{tabular}{|c|c|c|c|c|c|c|c|}
\hline \multirow[b]{2}{*}{ Category } & \multirow[b]{2}{*}{ Family } & \multirow[b]{2}{*}{ Type } & \multirow[b]{2}{*}{ Model } & \multirow[b]{2}{*}{ Dimensions } & \multicolumn{3}{|c|}{ MEP } \\
\hline & & & & & External material & system & 3D model \\
\hline \multirow{11}{*}{$\begin{array}{l}\text { Mechanical } \\
\text { equipment }\end{array}$} & Solar & Heat & Zelios & $1380 * 1910 * 178$ & Glass & Hydronic & \\
\hline & Collector & $\begin{array}{l}\text { Pipe - } \\
01\end{array}$ & VDF-15 & & $\begin{array}{l}\text { pipe/Aluminun } \\
\text { frame }\end{array}$ & System & \\
\hline & & Heat & Zelios & $1840 * 1910 * 178$ & Glass & & \\
\hline & & $\begin{array}{l}\text { Pipe - } \\
02\end{array}$ & VDF-20 & & $\begin{array}{l}\text { pipe/Aluminun } \\
\text { frame }\end{array}$ & & \\
\hline & & Heat & ILHC- & $1894 * 2310 * 135$ & Glass & & \\
\hline & & $\begin{array}{c}\text { Pipe - } \\
03\end{array}$ & 5830 & & $\begin{array}{l}\text { pipe/Aluminun } \\
\text { frame }\end{array}$ & & \\
\hline & & $\begin{array}{c}\text { Plano - } \\
01\end{array}$ & $\begin{array}{l}\text { Wunder } \\
\text { CLS } 2108\end{array}$ & $1988 * 1041 * 90$ & Tempered glass & & \\
\hline & & $\begin{array}{c}\text { Plano - } \\
02\end{array}$ & $\begin{array}{l}\text { Wunder } \\
\text { CLS } 2510\end{array}$ & $1988 * 1218 * 90$ & Tempered glass & & \\
\hline & Accumulator & $\begin{array}{l}A C- \\
200\end{array}$ & BST 200 & $1260 * 500$ & & $\begin{array}{l}\text { Hidronic } \\
\text { system, }\end{array}$ & \\
\hline & & $\begin{array}{l}A C- \\
300\end{array}$ & BST 300 & $1400 * 550$ & & $\begin{array}{l}\text { Hot water } \\
\text { system, }\end{array}$ & \\
\hline & & $\begin{array}{l}A C- \\
500\end{array}$ & BST 500 & $1695 * 650$ & & $\begin{array}{l}\text { water } \\
\text { system }\end{array}$ & \\
\hline
\end{tabular}

\section{Calculation of the Solar Thermal System components}

The catchment area and the capacity of the accumulator of the STS to supply the demand of domestic hot water are calculated. This process was done according to the Chilean law 20.365, and it was defined in an Excel spreadsheet in which were inserted input values needed for the final calculus.

This procedure requires data of: daily demand, housing demand, energy annual demand, solar fraction, the performance of the STS and the annual radiation collected. This last amount depends on of data extracted from the 3D model housing as the angle of roof and azimuth; and may vary according to the location of the house to assessing possibilities of adaptation of the STS.

The daily demand of hot water at a temperature of $45^{\circ} \mathrm{C}$ is estimated, and daily hot water consumption per person regarded equal to $40 \mathrm{~L} /$ day (Cp) for single-family houses (Ministerio de Hacienda, 2010). Similarly, the number of 
people who inhabit a house is calculated according to the values in Table 4, which serve as a basis for calculating the demand of domestic hot water of a housing (Dv) according to the following expression:

$D v=C p^{*} N$ o of people

Table 4. Number of people living in the house. Source: Ministerio de Hacienda (2010).

\begin{tabular}{lllllll}
\hline Room Amount & 1 & 2 & 3 & 4 & 5 & $>5$ \\
\hline People Amount & 1.5 & 3 & 4 & 6 & 7 & Room amount \\
\hline
\end{tabular}

Once calculated the demand for domestic hot water (Dv) it is proceed to calculate annual energy (DEacs), which represents the amount of energy required to raise the temperature of the flow of water from the inlet temperature of the cold water until the temperature at the points of consumption (Ministerio de Energía et al., 2010). It is calculated using the following expression:

$$
\text { DEacs }=Q(T u) * \rho * C p *(T u-T a f)
$$

where:

DEacs $=$ Annual energy demand

$Q(T u)=$ Water flow consumption

$\rho=$ Water density

$C p=$ Specific Heat of water

$T u=$ Temperature of consumption of the water

Taf $=$ Water inlet temperature

The solar fraction of the system (Fs), also called coverage or solar contribution, is the share of the energy demand covered by solar energy. The initial criterion of calculation is select the installation that justifies, as minimum, the compliance of the conditions established in the normative like minimum solar contribution depending on the geographical location (Ministerio de Energía et al., 2010).

In this case, (Ministerio de Hacienda, 2010) defines that the city of Concepcion belongs to the climate zone C, and therefore requires a minimum solar contribution of $57 \%$. This is the value that will be taken as a basis for sizing the STS in a first step, then the most optimal value according to the catchment area of the solar collectors will be established.

The accurate of the efficiency of STS is regarded in the calculation process in which all their variables are interrelated, but its estimation facilitates the installations size assessment (Ministerio de Energía et al. 2010). Since this research focuses on the sizing of the STS to integrate into the architecture of a house in the early stages of the design, it will be taken as reference data from the work "Experimental validation of SDHW systems and parametric study on their performance based on dwelling characteristics" (Jerez, Cuevas, \& Fissore, 2016), where the evaluation of a solar thermal system with flat collector annual simulation throws system efficiency of $45 \%$.

This value matches the approximate estimation according to (Ministerio de Energía et al., 2010) which says that the average annual performance of the solar installation depends on the mean yield of the solar collectors, that $40-60 \%$ is usually included in the range. It is also estimated that the rest of the installation components introduce additional thermal losses that contribute to reducing this performance, these losses should never be higher than $20 \%$ and, therefore, values of average annual yield can be estimated for the complete installation within the range of 30 to $50 \%$.

To calculate the solar collector's area is necessary to have the solar annual radiation value on a plane with the same orientation and inclination, which in this case is the roof side for an architectural integration of the panel. Then, this data is defined by the slope and the azimuth of the cover selected. These annual radiation values are taken from Meteonorm data of the Concepcion's airport (WMO Index number 856820) through a table created with different angles of inclination and azimuth (Table 5)

Finally, the collector area (Ac) allows to select the type and quantity of solar collectors to be used according to the parametric families, and is determined based on the following expression:

$$
A C * H t * \eta N S T=F s * D E a c s
$$

where:

Ac $=$ Collector surface 
$\mathrm{Ht}=$ Global annual radiation

ПNST = Global performance of the solar installation

Fs $=$ Solar Fraction

DEacs = Annual energy demand

The volume of the accumulation system depends on collectors area, using a specific value of 75 litre of accumulation per square meter of thecatchment (Ministerio de Energía et al., 2010). Maybe formed by one or more deposits accumulators and the volume total of them accumulators must be according with the demand and have a value that meets the following condition:

\section{$40 \leq \mathrm{V} / \mathrm{A} \leq 180$}

where:

$A=$ Surface installed of STS

$\mathrm{V}=$ The accumulator volume

Table 5. Total annual Radiation $\left(\mathrm{Kwh} / \mathrm{m}^{2}\right)$ according to azimuth and slope in Concepción, Chile. Source: The author.

\begin{tabular}{|c|c|c|c|c|c|c|c|c|c|c|c|c|c|c|c|c|c|c|c|c|c|}
\hline \multirow{2}{*}{$\begin{array}{l}\text { RADIATION } \\
\text { AZIMUTH }\end{array}$} & \multicolumn{20}{|c|}{ INCLUNATION } & \multirow[b]{2}{*}{ TOTAL } \\
\hline & 0 & 5 & 10 & 15 & 20 & 25 & 30 & 35 & 37 & 40 & 45 & 50 & 55 & 60 & 65 & 70 & 75 & 80 & 85 & 90 & \\
\hline-170 & 1533 & 1482 & 1424 & 1357 & 1284 & 1205 & 1123 & 1043 & 1010 & 963 & 885 & 810 & 738 & 670 & 608 & 552 & 508 & 479 & 459 & 442 & 18575 \\
\hline-160 & 1533 & 1484 & 1428 & 1363 & 1292 & 1217 & 1138 & 1058 & 1026 & 980 & 903 & 829 & 759 & 694 & 634 & 584 & 547 & 517 & 492 & 471 & 18949 \\
\hline-150 & 1533 & 1488 & 1434 & 1374 & 1307 & 1235 & 1161 & 1085 & 1055 & 1010 & 936 & 866 & 799 & 739 & 686 & 641 & 602 & 569 & 540 & 513 & 19573 \\
\hline-140 & 1533 & 1492 & 1444 & 1388 & 1326 & 1261 & 1192 & 1122 & 1095 & 1053 & 985 & 920 & 860 & 804 & 753 & 708 & 666 & 629 & 595 & 564 & 20390 \\
\hline-130 & 1533 & 1498 & 1455 & 1406 & 1351 & 1292 & 1230 & 1168 & 1143 & 1105 & 1044 & 985 & 928 & 875 & 826 & 779 & 736 & 695 & 657 & 621 & 21327 \\
\hline-120 & 1533 & 1505 & 1469 & 1426 & 1379 & 1327 & 1273 & 1218 & 1196 & 1162 & 1107 & 1053 & 1000 & 949 & 900 & 852 & 807 & 763 & 721 & 680 & 22320 \\
\hline-110 & 1533 & 1512 & 1484 & 1449 & 1409 & 1366 & 1319 & 1271 & 1251 & 1222 & 1172 & 1121 & 1071 & 1022 & 973 & 924 & 877 & 830 & 784 & 739 & 23329 \\
\hline-100 & 1533 & 1520 & 1500 & 1473 & 1441 & 1405 & 1366 & 1324 & 1307 & 1281 & 1235 & 1188 & 1141 & 1092 & 1043 & 993 & 943 & 894 & 844 & 795 & 24318 \\
\hline-90 & 1533 & 1529 & 1516 & 1498 & 1474 & 1445 & 1413 & 1377 & 1362 & 1338 & 1296 & 1252 & 1206 & 1158 & 1108 & 1057 & 1005 & 952 & 899 & 846 & 25264 \\
\hline-80 & 1533 & 1537 & 1533 & 1522 & 1506 & 1484 & 1458 & 1427 & 1413 & 1392 & 1353 & 1311 & 1266 & 1218 & 1167 & 1115 & 1060 & 1004 & 947 & 890 & 26136 \\
\hline-70 & 1533 & 1545 & 1549 & 1546 & 1537 & 1521 & 1500 & 1474 & 1462 & 1442 & 1406 & 1365 & 1321 & 1272 & 1220 & 1165 & 1108 & 1049 & 988 & 927 & 26930 \\
\hline-60 & 1533 & 1553 & 1564 & 1568 & 1565 & 1555 & 1539 & 1516 & 1506 & 1488 & 1453 & 1414 & 1369 & 1319 & 1266 & 1208 & 1148 & 1085 & 1020 & 954 & 27623 \\
\hline-50 & 1533 & 1560 & 1578 & 1588 & 1591 & 1586 & 1574 & 1554 & 1544 & 1528 & 1495 & 1456 & 1410 & 1360 & 1304 & 1244 & 1180 & 1113 & 1044 & 974 & 28216 \\
\hline-40 & 1533 & 1566 & 1590 & 1606 & 1613 & 1612 & 1604 & 1587 & 1578 & 1562 & 1530 & 1491 & 1445 & 1393 & 1335 & 1273 & 1205 & 1134 & 1061 & 985 & 28703 \\
\hline-30 & 1533 & 1571 & 1600 & 1620 & 1631 & 1634 & 1628 & 1613 & 1605 & 1590 & 1559 & 1520 & 1474 & 1420 & 1360 & 1294 & 1223 & 1148 & 1070 & 989 & 29082 \\
\hline-20 & 1533 & 1575 & 1607 & 1631 & 1645 & 1650 & 1647 & 1634 & 1626 & 1612 & 1581 & 1542 & 1494 & 1439 & 1378 & 1309 & 1235 & 1156 & 1073 & 987 & 29354 \\
\hline-10 & 1533 & 1577 & 1612 & 1638 & 1654 & 1661 & 1658 & 1646 & 1639 & 1625 & 1595 & 1555 & 1508 & 1452 & 1388 & 1318 & 1241 & 1159 & 1073 & 983 & 29515 \\
\hline 0 & 1533 & 1578 & 1614 & 1640 & 1657 & 1665 & 1663 & 1652 & 1644 & 1631 & 1600 & 1561 & 1513 & 1457 & 1394 & 1323 & 1245 & 1162 & 1074 & 982 & 29588 \\
\hline 10 & 1533 & 1577 & 1613 & 1639 & 1656 & 1663 & 1661 & 1649 & 1642 & 1629 & 1598 & 1560 & 1512 & 1456 & 1393 & 1323 & 1246 & 1164 & 1077 & 987 & 29578 \\
\hline 20 & 1533 & 1576 & 1609 & 1634 & 1649 & 1655 & 1652 & 1640 & 1632 & 1618 & 1588 & 1550 & 1503 & 1448 & 1386 & 1318 & 1243 & 1164 & 1081 & 994 & 29473 \\
\hline 30 & 1533 & 1572 & 1603 & 1624 & 1637 & 1641 & 1636 & 1623 & 1615 & 1601 & 1570 & 1532 & 1485 & 1432 & 1372 & 1306 & 1235 & 1159 & 1080 & 999 & 29255 \\
\hline 40 & 1533 & 1568 & 1594 & 1611 & 1620 & 1621 & 1614 & 1598 & 1590 & 1575 & 1544 & 1506 & 1460 & 1408 & 1351 & 1287 & 1220 & 1148 & 1073 & 997 & 28918 \\
\hline 50 & 1533 & 1562 & 1582 & 1595 & 1599 & 1596 & 1586 & 1568 & 1559 & 1543 & 1511 & 1472 & 1428 & 1377 & 1322 & 1261 & 1197 & 1129 & 1059 & 988 & 28467 \\
\hline 60 & 1533 & 1555 & 1569 & 1576 & 1575 & 1567 & 1553 & 1532 & 1522 & 1505 & 1472 & 1433 & 1388 & 1339 & 1285 & 1228 & 1167 & 1103 & 1037 & 970 & 27909 \\
\hline 70 & 1533 & 1548 & 1555 & 1554 & 1547 & 1534 & 1515 & 1491 & 1480 & 1461 & 1426 & 1386 & 1342 & 1293 & 1241 & 1186 & 1128 & 1068 & 1006 & 944 & 27238 \\
\hline 80 & 1533 & 1540 & 1539 & 1531 & 1517 & 1498 & 1474 & 1445 & 1432 & 1412 & 1374 & 1333 & 1288 & 1240 & 1190 & 1136 & 1081 & 1024 & 966 & 908 & 26461 \\
\hline 90 & 1533 & 1532 & 1522 & 1507 & 1486 & 1460 & 1430 & 1396 & 1381 & 1358 & 1318 & 1274 & 1229 & 1180 & 1130 & 1079 & 1026 & 972 & 918 & 864 & 25595 \\
\hline 100 & 1533 & 1523 & 1506 & 1482 & 1453 & 1420 & 1383 & 1344 & 1327 & 1301 & 1257 & 1211 & 1163 & 1114 & 1065 & 1014 & 964 & 913 & 862 & 812 & 24647 \\
\hline 110 & 1533 & 1515 & 1489 & 1457 & 1421 & 1380 & 1336 & 1290 & 1271 & 1242 & 1193 & 1143 & 1093 & 1043 & 994 & 944 & 896 & 848 & 801 & 755 & 23644 \\
\hline 120 & 1533 & 1507 & 1474 & 1434 & 1389 & 1341 & 1289 & 1236 & 1214 & 1182 & 1127 & 1073 & 1021 & 969 & 919 & 871 & 824 & 779 & 736 & 694 & 22612 \\
\hline 130 & 1533 & 1500 & 1460 & 1413 & 1360 & 1304 & 1245 & 1184 & 1159 & 1123 & 1062 & 1004 & 947 & 894 & 843 & 796 & 751 & 710 & 670 & 633 & 21591 \\
\hline 140 & 1533 & 1494 & 1447 & 1394 & 1335 & 1271 & 1205 & 1136 & 1109 & 1068 & 1002 & 937 & 877 & 821 & 769 & 722 & 680 & 642 & 607 & 575 & 20624 \\
\hline 150 & 1533 & 1489 & 1437 & 1378 & 1313 & 1244 & 1171 & 1096 & 1067 & 1022 & 950 & 880 & 814 & 754 & 700 & 654 & 614 & 579 & 548 & 521 & 19764 \\
\hline 160 & 1533 & 1485 & 1430 & 1366 & 1297 & 1222 & 1144 & 1066 & 1035 & 989 & 913 & 840 & 770 & 704 & 644 & 593 & 554 & 523 & 498 & 476 & 19082 \\
\hline 170 & 1533 & 1483 & 1425 & 1359 & 1286 & 1208 & 1127 & 1047 & 1015 & 968 & 890 & 816 & 744 & 675 & 613 & 557 & 512 & 483 & 461 & 444 & 18646 \\
\hline 180 & 1533 & 1482 & 1423 & 1356 & 1282 & 1203 & 1120 & 1039 & 1007 & 959 & 881 & 806 & 733 & 664 & 600 & 544 & 497 & 466 & 447 & 432 & 18474 \\
\hline
\end{tabular}


To relate the inputs and to calculate the solar collectors area in the case of study $A$, am spreadsheet was created in Excel and the equations and data identified previously were inserted (Table 6). In addition, a data base is created with the parametric families of already identified accumulators and solar collectors (Table 7). The area of each of these components is related to the calculated surface of collectors to select the type of collector and storage tank that fits better to the requirements of the system.

Table 6. Calculation of the STS in Excel. Source: The author. Calculation of Collectors area and Accumulator capacity

\begin{tabular}{|c|c|c|}
\hline Inputs & Quantity & Unit \\
\hline People Amount & 4 & \\
\hline Daily demand & 40 & I/day \\
\hline $\begin{array}{l}\text { Domestic hot water } \\
\text { consumption }\end{array}$ & 160 & I/day \\
\hline Annual energy demand & 2234.1 & Kwh/year \\
\hline Solar Fraction & 57 & $\%$ \\
\hline Solar Thermal System efficiency & 45 & $\%$ \\
\hline Angle & 40 & degree \\
\hline Azimuth & 0 & degree \\
\hline Total radiation & 1631 & $\mathrm{KWh} / \mathrm{m}^{2}$ year \\
\hline \multicolumn{3}{|l|}{ Outputs } \\
\hline Collector area & 1.74 & $m^{2}$ \\
\hline Accumulator capacity & 130.1 & I \\
\hline
\end{tabular}

\begin{tabular}{lcc}
\multicolumn{3}{l}{ Table 7. Database of parametric families of the STS components. Source: The author. } \\
\hline Family & Family Type & Area $\left(\mathrm{m}^{2}\right)$ \\
\hline Heat Pipe & Heat Pipe - 01 & 2.6 \\
collector & Heat Pipe -02 & 3.5 \\
& Heat Pipe -03 & 4.6 \\
Plane collector & Plano - 01 & 2.0 \\
& Plano - 02 & 2.4 \\
Family & Family Type & Volume (I) \\
Accumulator & AC - 200 & 200 \\
& AC - 300 & 300 \\
& AC - 500 & 500 \\
\hline
\end{tabular}

The Table 8 summarizes the information obtained, by selecting the category of collector to define the amount and type of family to be used. The solar fraction is set to the catchment area obtained with the collectors selected. The validation of the system allows to know if this complies with the minimum solar contribution required by the regulation of the law 20.365 determined by the following relationship:

where:

$$
\mathrm{CS} \geq \mathrm{CSM}^{*} 0.85
$$

CS: Solar contribution of the STS [\%].

CSM: Required minimum solar contribution [\%].

In the case of study A (inclination 40 and azimuth $0^{\circ}$ ) the applied methodology allowed to determine that it needs to be a catchment area of $1.74 \mathrm{~m}^{2}$ and a capacity of the accumulator equal to 130.1 litres. To comply with these requirements, the database of solar thermal components integrated to the Excel table allowed determining two options of installation.

A first case where the collector called "Heat Pipe - 01" with an area of $2.6 \mathrm{~m}^{2}$ provides a solar fraction of $85 \%$, and a second case where the plane collector of type "plane - 01" of area equal to $2.0 \mathrm{~m}^{2}$ obtains a solar fraction of $65.7 \%$; both cases with an accumulator of 200 liters of capacity. To evaluate both options it is convenient to use the collector of the second alternative because its annual solar fraction does not exceed the critical value $75 \%$, according to the FChart calculation program. Oversupply generate a thermal energy production increased to $90 \%$ in the summer months, producing risks of overheating of the STS (as it is the case of the Heat Pipe collector - 01). 


\begin{tabular}{|c|c|c|c|}
\hline \multicolumn{4}{|c|}{ Collector category: $1=$ Heat Pipe; 2= Plane collector } \\
\hline 2 & $\begin{array}{l}\text { Collector } \\
\text { Area }\end{array}$ & $\begin{array}{l}\text { Collector } \\
\text { Type }\end{array}$ & Quantity \\
\hline $\begin{array}{l}\text { Collector to } \\
\text { install }\end{array}$ & 2 & Plane - 01 & 1 \\
\hline Accumulator & 200 & AC-200 & 1 \\
\hline \multicolumn{3}{|c|}{$\begin{array}{l}\text { Solar contribution (CS) with the collectors } \\
\text { selected (\%) }\end{array}$} & 65.7 \\
\hline \multicolumn{3}{|c|}{$\begin{array}{l}\text { Verification of minimum Solar contribution } \\
\mathrm{CS} \geq \mathrm{CSM}^{*} 0.85(48.45 \%)\end{array}$} & YES \\
\hline
\end{tabular}

\section{Algorithm programmatic with Dynamo + Ladybug}

Through the implementation of the algorithm with Dynamo language, has been devised with a set of operations that allows generating an exchange of information between the 3D Revit model and an Excel spreadsheet. In order to define the solar components to integrate into the STS depending on the house variables concerning orientation and inclination angle of the roof (Figure 3). Also the insertion point of the solar panels is defined according to the solar potential of the roof.

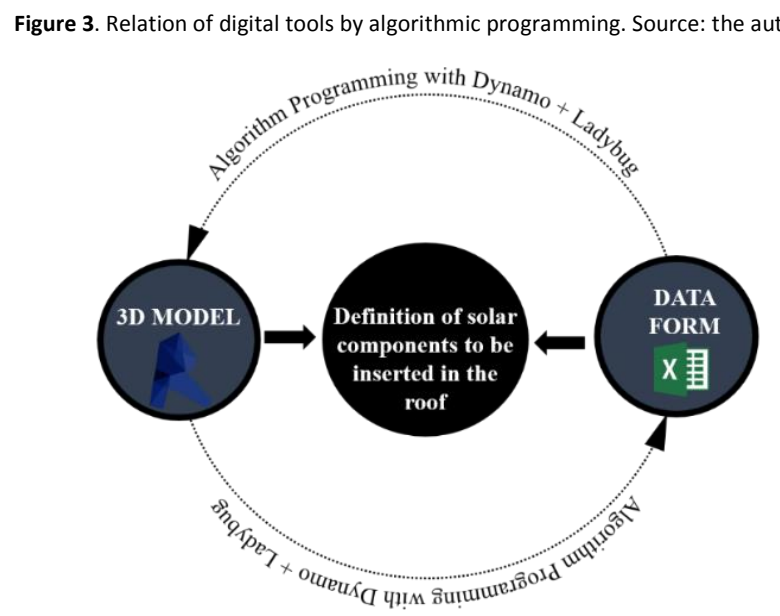

The interoperability of the software allows inserting in the table created in Excel the inputs that it needs to carry out the dimensioning of the STS according to the method established. Through Dynamo the node 1 is created and allows to identify the housing surface with greater solar potential according to the analysis performed with Ladybug as energy Simulator, which determines the levels of radiation incidents on each roof side and extracted parameters of inclination and azimuth angle that later with the node 2 are exported and inserted in the Excel spreadsheet (Figure 4).

Figure 4. Algorithmic programming to define the surface with greater solar potential and extract inclination and azimuth data to the STS calculation. Source: the author. 


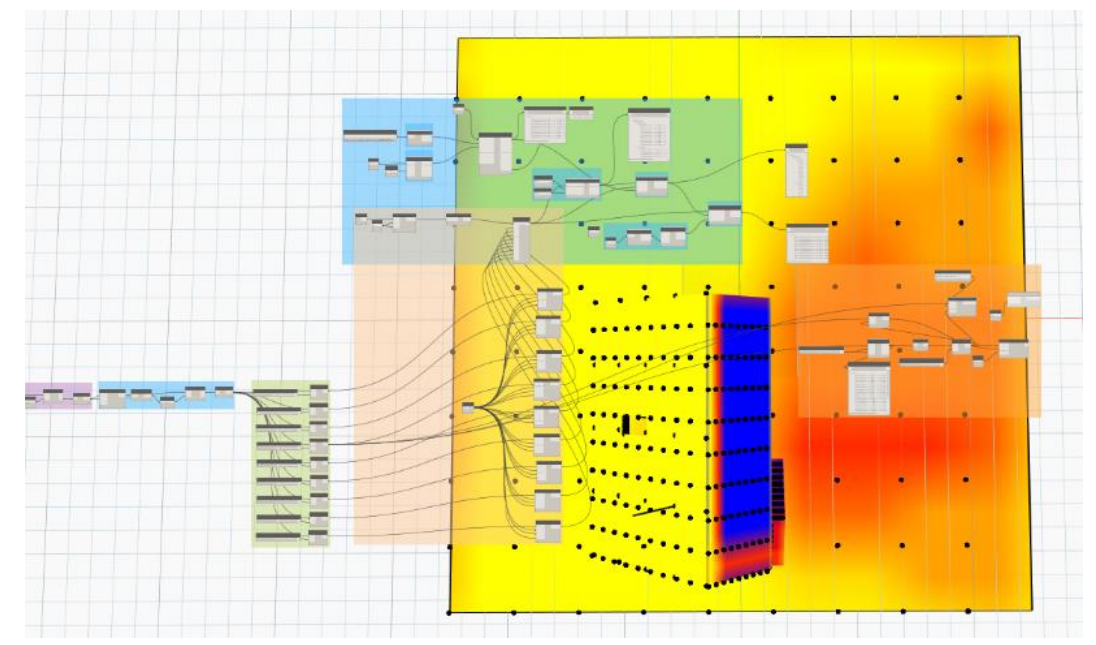

The relationship created starting from these nodes allows returning information to Dynamo with modifications defined in Excel. This condition allows to supplying the data in the algorithm relating to the type and amount of parametric families to insert in the model through the node 3. With this information, it is determined the insertion point of the solar collectors in the roof through a grid to indicate the point manually, and it is indicated the type of family to insert with the node 4 (Figure 4).

Finally, the algorithm created in Dynamo allows the inclusion of the parametric family of the solar collector and the storage tank in the housing type (Figure 5). This process regard that any variation in the configuration of the roof will affect directly the algorithmic programming created.

Figure 5. Insertion of parametric families in the model using the algorithmic programming. Source: the author.

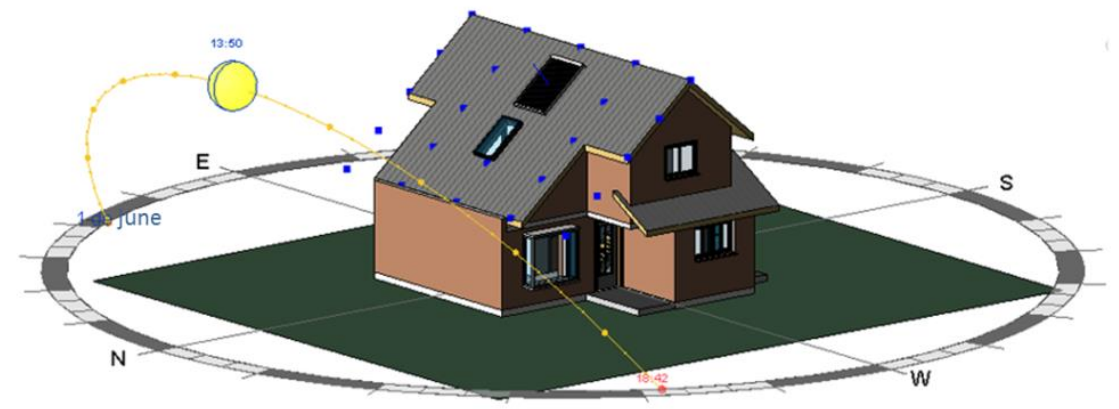

\section{Piping system design with MEP}

The design of piping systems with MEP utilities in Revit allows relating all the components of the STS inserted in the model, optimizing the routing and connections between the fittings and mechanical equipment. Three subsystems are identified: water cold system, hot water system and hydronic system. The latter is used for heat exchange, for heating or cooling processes for human comfort, using the liquid as a means of transport of heat (thermal energy), in this case it is represented by the closed circuit between the solar collector and the storage tank of the STS (Figure 6).

The tool selected allows creating the pipes circuits and doing the calculation of them according to the parameters already established of the accessories of parametric families, with the flow assigned to each type of this family. Also, it checks the behaviour of the installation in general and the need of making some change in the architecture of the house for its integration. 


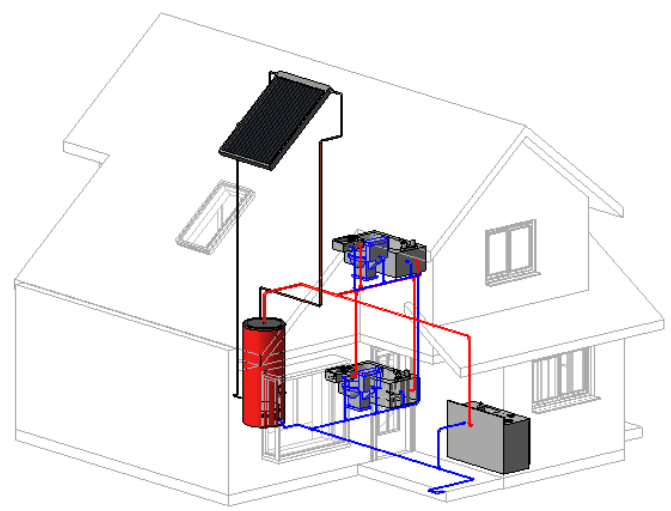

Result

A parametric analysis based on two case-studies was done, exploring variations in the azimuth angle of the collectors with respect to the North to generate an array of 8 orientation possibilities (Figure 7). The analysis aims to identify changes in the type and number of solar components when the solar orientation of the house is modified (keeping in both cases a provision of $2234.1 \mathrm{Kwh} /$ year).

In the first model, the azimuth angles between $0^{\circ}$ and $90^{\circ}$ required collection area between $1.71 \mathrm{~m}^{2}$ and $2.12 \mathrm{~m}^{2}$. Azimuth of $-135^{\circ}$ and $-180^{\circ}$ increased this surface to $2.56 \mathrm{~m}^{2}$ and $2.94 \mathrm{~m}^{2}$, respectively. Recommending the use of a collector type "Plane - 01" for angles ranging from $0^{\circ}$ to $45^{\circ}$, while for an azimuth of $90^{\circ}$ is chosen a collector type "Plano - 02", both with an accumulator of type "AC - 200" to get a solar fraction less than $75 \%$ in the full set (critical value).

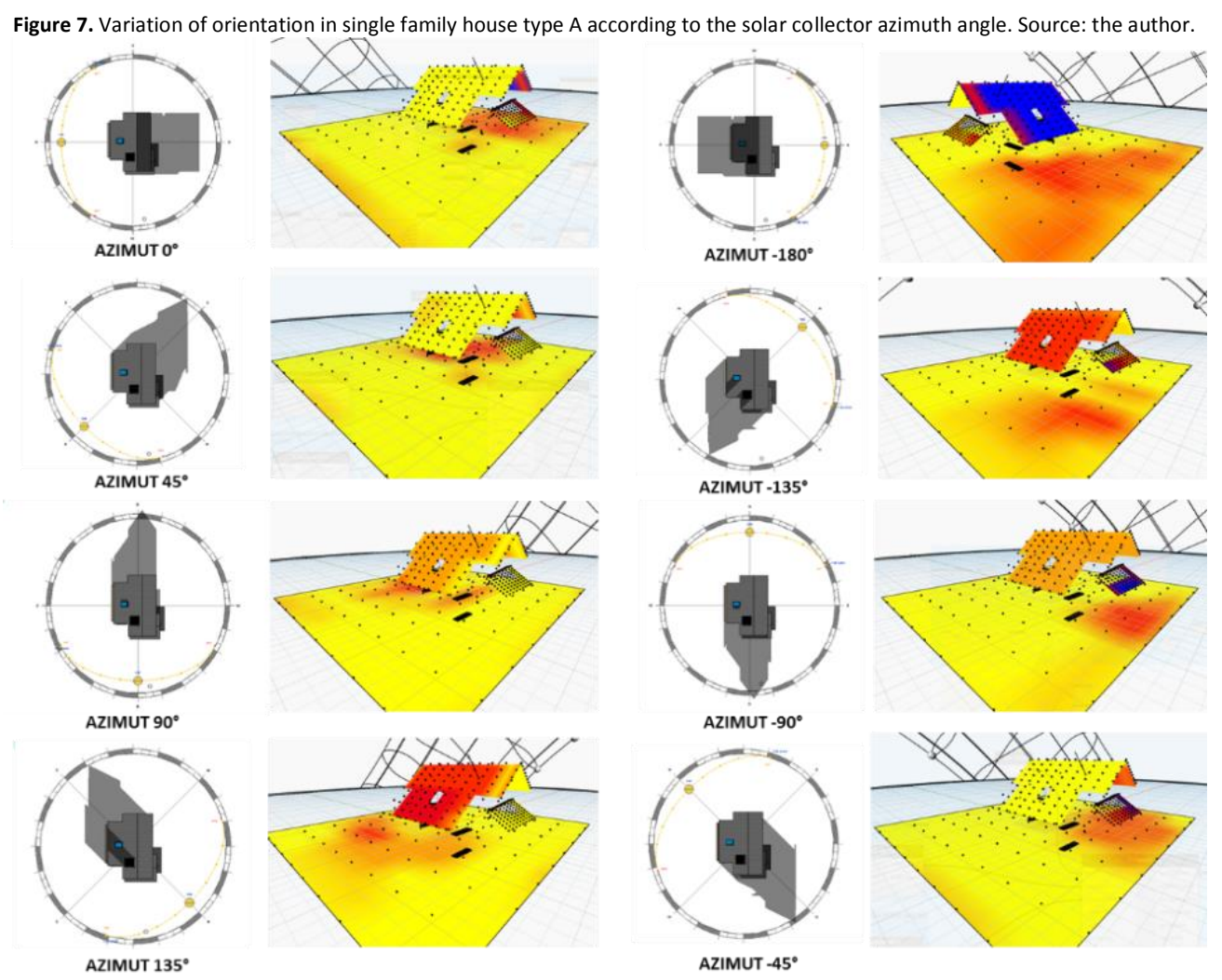

In contrast, to azimuth angles between $90^{\circ}$ and $135^{\circ}$ the Heat pipe collectors optimizes the STS operation, because the use of one collector type "Heat Pipe - 01" with an accumulator "AC-200" adjusts the solar fraction to values close to $70 \%$. The Chart 2 shows that for orientations opposite to the solar travel (- $135^{\circ}$ and $\left.180^{\circ}\right)$, the types "Heat Pipe - 01" and "Heat Pipe-02" give less than $75 \%$ solar fraction, which is an optimal option to use in housing. 


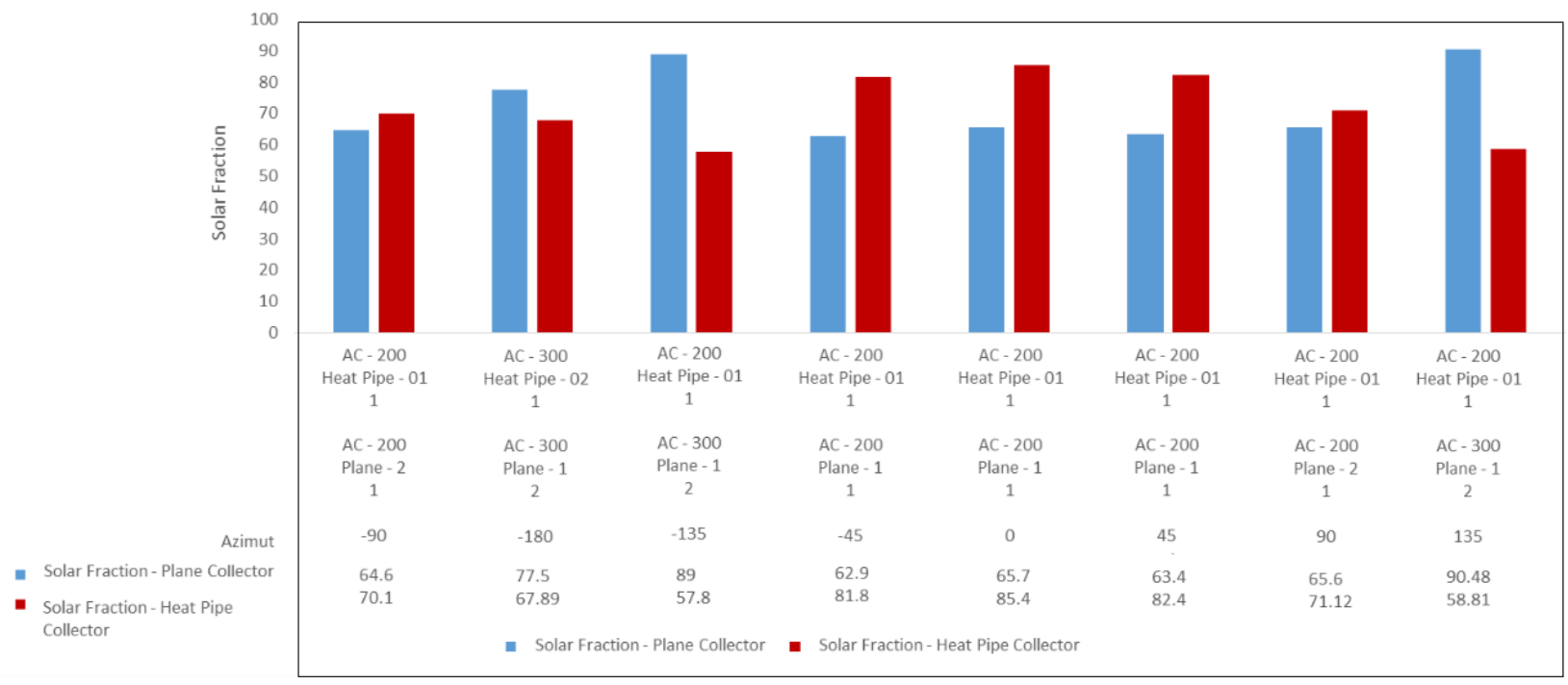

The second case-study (Figure 9) changes the roof inclination to $27^{\circ}$, obtaining a similar behaviour to the previous one in orientations with an azimuth between $0^{\circ}$ and $90^{\circ}$. However, solar collector area decreases between $2.17 \mathrm{~m}^{2}$ and $2.35 \mathrm{~m}^{2}$ respectively for opposite orientations to the solar travel (azimuth $-135^{\circ}$ and $180^{\circ}$ ). The behaviour of the plane collectors generates a solar fraction of the system less than $67 \%$ in all orientations, then it recommends the use of a collector type "Plane - 01" with accumulator "AC-200" for all the alternatives that are within the solar travel (from $0^{\circ}$ to $90^{\circ}$ azimuth). Changing the type to "Plane - 02" when it has an opposite direction to the North (-135 ${ }^{\circ}$ and -180 $\left.{ }^{\circ}\right)$.

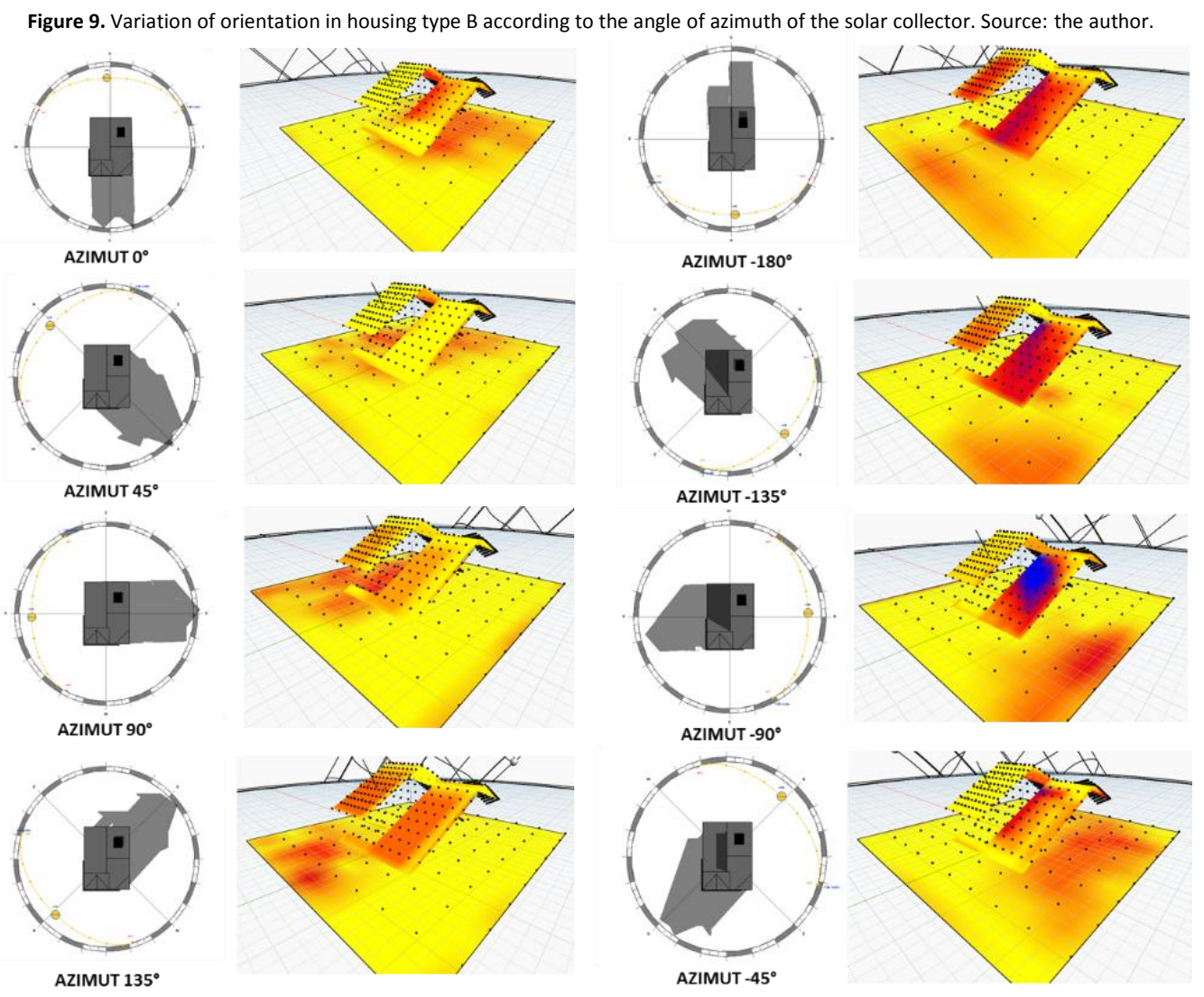

The roof inclination of $27^{\circ}$ has a requirement of catchment surface lower by the Heat pipe collector, demonstrating it in the fraction solar values that generate in the STS with orientations between $0^{\circ}$ and $90^{\circ}$, with percentages higher to the critical value (75\%). However, as in the case of study $A$, the performance of these collectors are optimized in positions contrary to the solar trajectory $\left(135^{\circ},-135^{\circ}\right.$ and $\left.-180^{\circ}\right)$ using a collector "Heat Pipe-01" and accumulator "AC- 
$200 "$ gets a solar fraction not greater to the $68 \%$, which is superior by the plane collectors in this orientation (Figure $10)$.

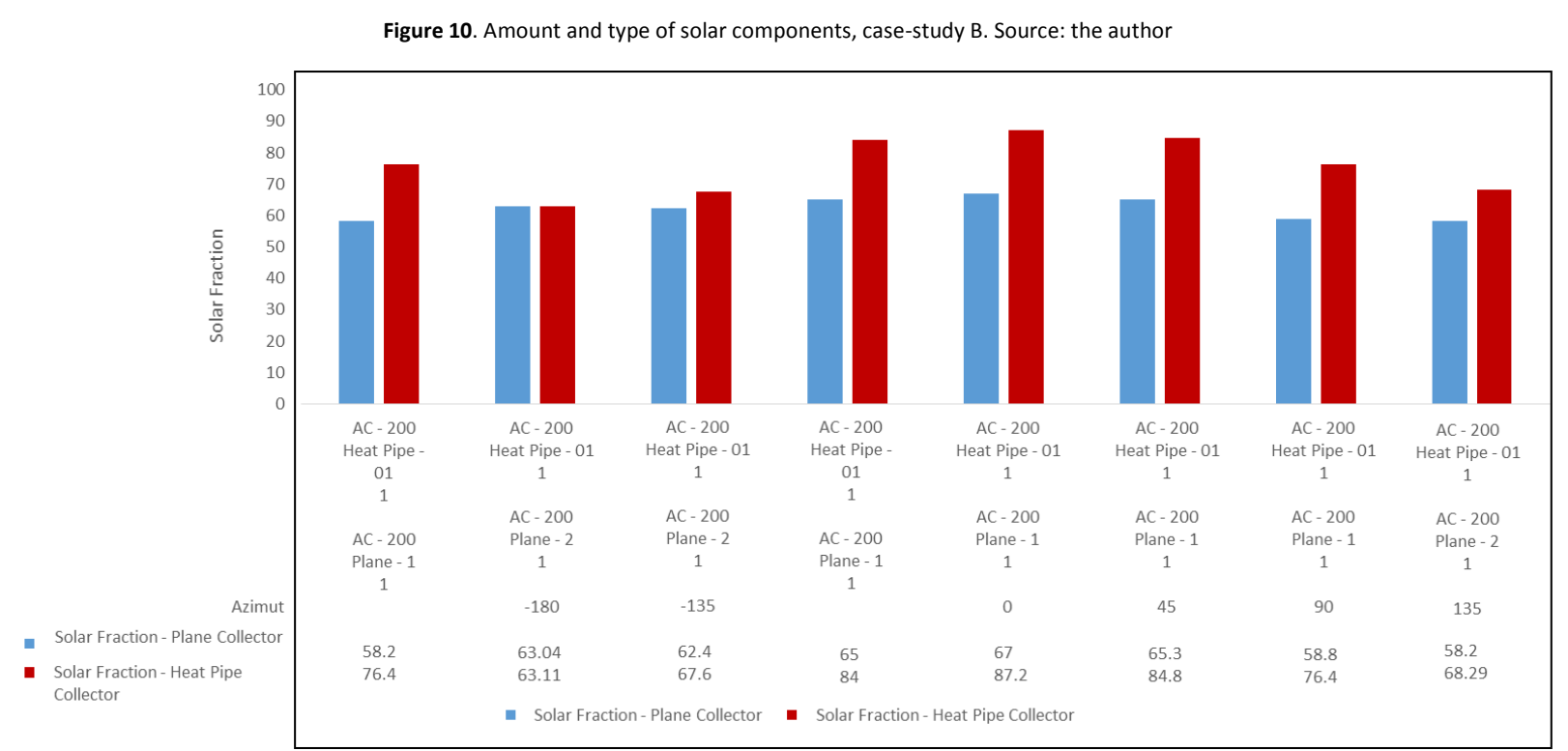

The analysis determined that the plane collectors types are adapted to efficient way in housing with roof side positive to the solar trajectory, and when the STS is orientated opposite to the solar trajectory can be optimize with Heat pipe collectors to increase the solar fraction of the system, between $10 \%$ and $20 \%$ depending on each case. Also, the inclination angle of $27^{\circ}$ contributes to improving its behaviour energy since the collectors solar receive greater amount of solar annual radiation.

Incorporating the costs of the accumulator and solar collector in the parametric analysis, helps to determine that there is a directly proportional relation between these parameters with the solar fraction value that contributes the STS. In the case-study A, the costs associated with the plane collector type, expressed in Figure 11, shows that it generates an excessive solar contribution of the system with azimuth angles between $135^{\circ}$ and $180^{\circ}$, which decreases its economic feasibility.

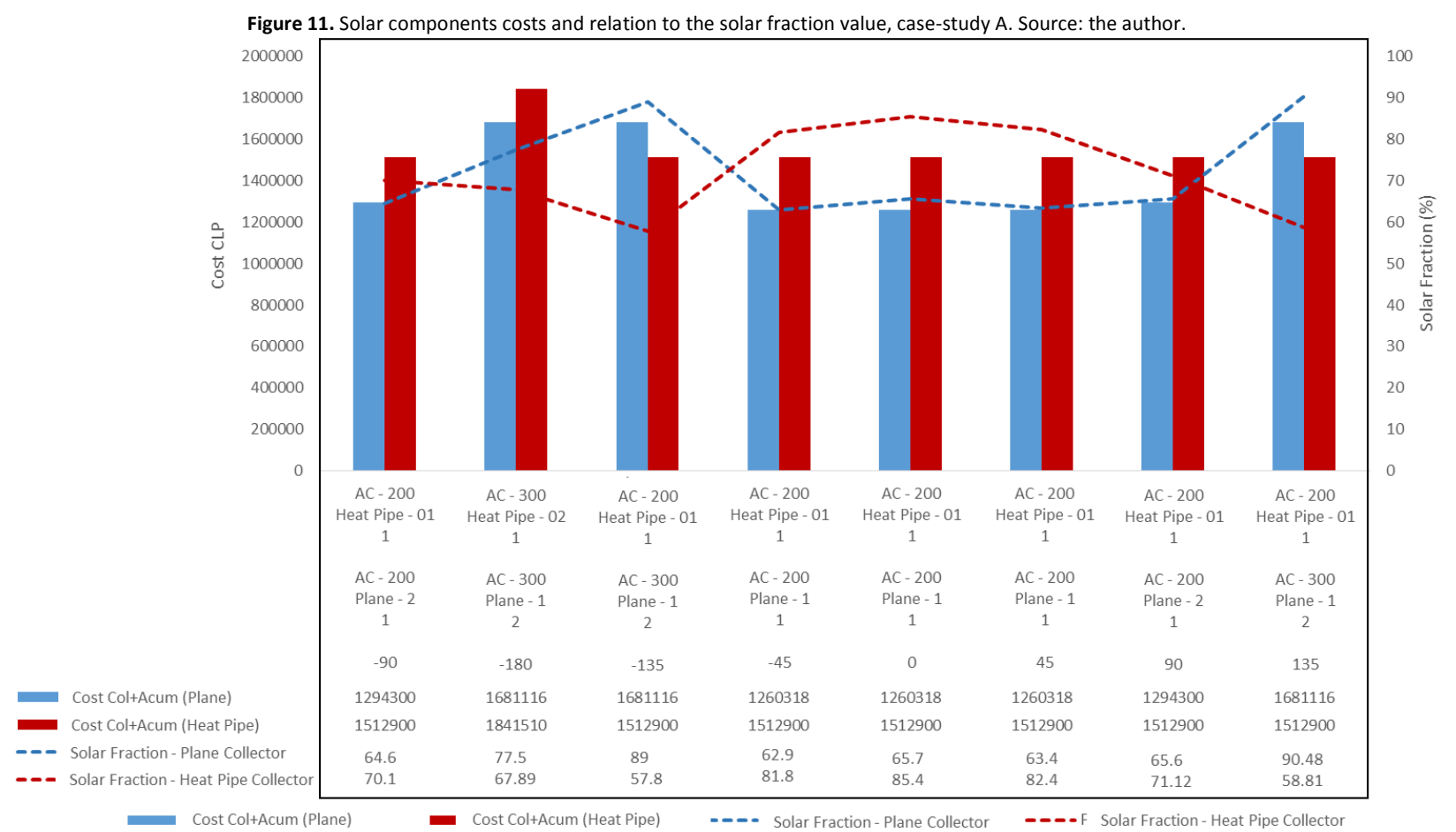

To know the economic feasibility of the STS with the use of Heat pipe collectors type, the Figure 11 shows how the use of these components generates two different scenarios. In a first case, it has a cost less of 168.216 CLP (Chilean Pesos) 
in orientation $-135^{\circ}$, representing a $10 \%$ less than the investment for collectors plane. In a second case it has an extra cost of $160.400 \mathrm{CLP}$ for orientations $-180^{\circ}$ (9.5\%). Demonstrating that the selection of these collectors improves the solar fraction values and requires an investment with little room for variation with regard to the alternative of plane collectors.

To analyze the case-study B, in the Figure 12 it is observes that the costs corresponding to install the plane collectors are similar, particularly the cost of solar components of type "plane - 01" presents a cost of 1.260.318 CLP with variation of a $4 \%$, to the change to type "Plane -02 ", representing a viable economic alternative. 


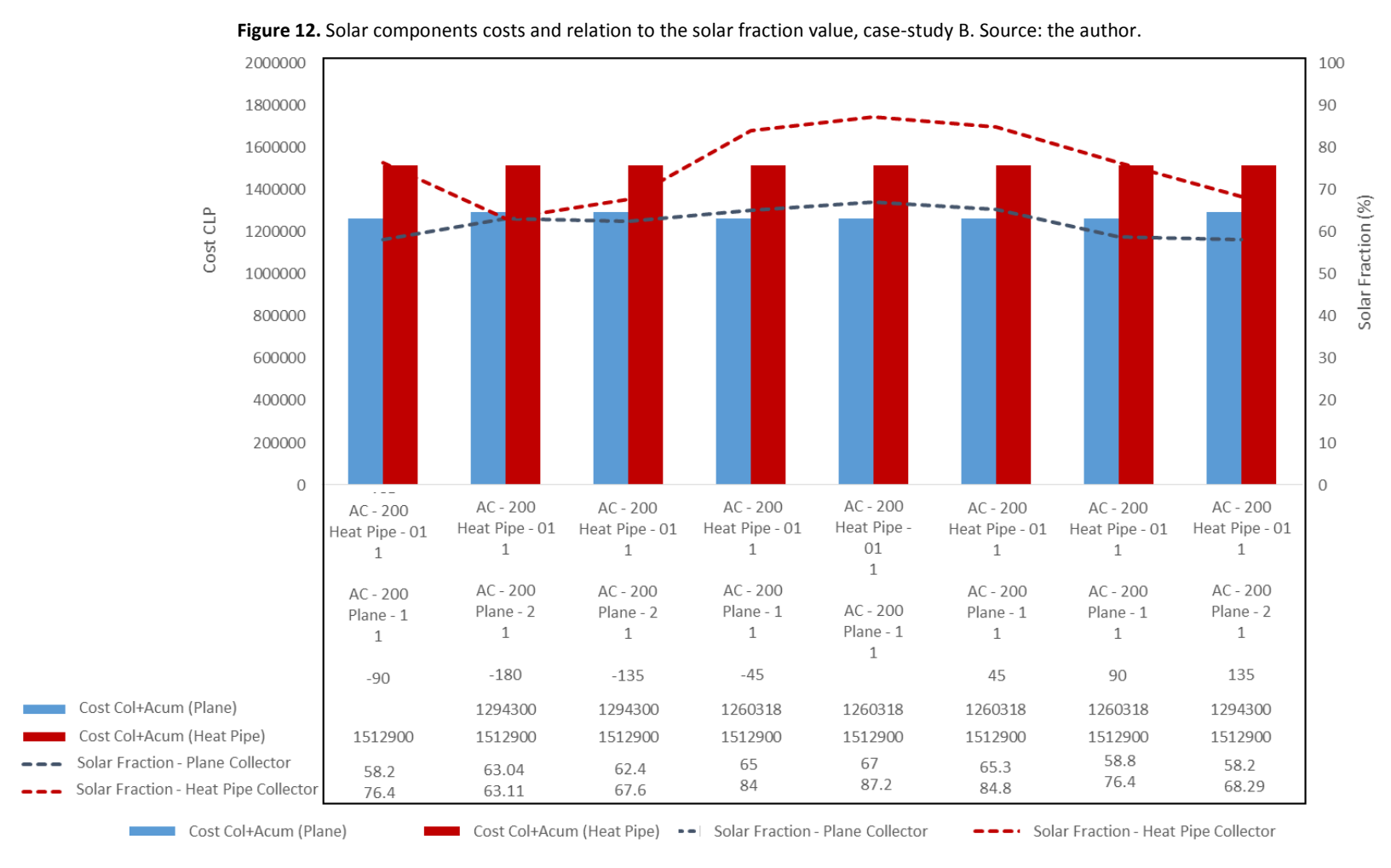

However, the type Heat pipe allows to improving the fraction solar of the system in a $15 \%$ and $23 \%$ in orientations 135 ${ }^{\circ}$ and $90^{\circ}$ respectively, with an increase of $20 \%$ respect to the cost of the plane collectors. These values allow inferring that there are no substantial differences between installing one or other component, according to the recommendations made at the monetary approach, the efficiency STS to install lies in the evaluation of the solar contribution depending on its orientation which proportionally affects the cost of its components.

Finally, interoperability of employed tools allows visualization of the housing with the STS integrated through the creation of render images (figure 13), demonstrating that both collectors types have the flexibility to be adapted in the roof of the house under the architectural integration criteria. By attaching to existing elements such as skylights and by adding a new function of solar filter that allows incorporating daylight in the living spaces (with type Heat pipe).

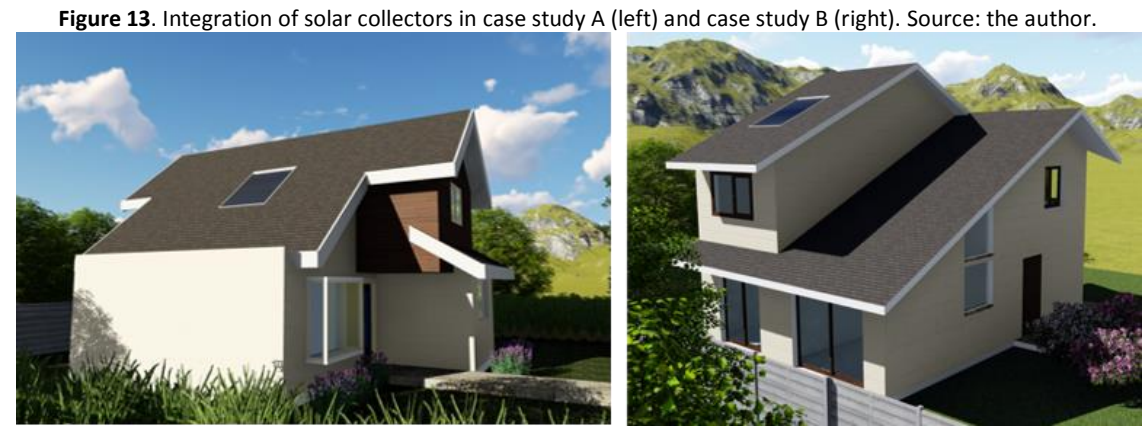

Conclusions

The study obtained an integrated design method to assess and integrates solar thermal systems in single houses that allowed to select products, insert and adapts automatically the parametric designs into the digital model. This method includes a solar products characterization and modeling of parametric families of each component, calculation of the solar energy potential of the housing roof, evaluation of the solar components according to demand of domestic hot water (HWS), quantification and integration of the solar thermal system (STS) in the housing model, layout of 
plumbing, budget and visualization of architectural integration. It identifies the type and number of components used in the STS based on its energy performance, which facilitates its incorporation in early stages of design.

The characteristics of solar components linked through algorithmic programming created in Dynamo in conjunction with Ladybug as energy simulator, allows the designer to select the more favorable location of the solar collector according to architectural and environmental needs, as well as exploring different alternatives of design. It generates opportunities of customizing the STS directly in the building without requiring data detailed of the project, achieving get results more optimal to reduce the possibilities of overproduction of energy thermal.

This experience allowed demonstrating the integration of solar thermal systems in the early design of houses, with the configuration of equipment according to the roof inclination, orientation, layout of pipes and accessories. It can be applied to more products, different geographic locations and designs of houses or buildings with a similar methodology. Particularly in early stages of building design with a quick energy performance evaluation and configuration to incorporate more properly these systems, to maintain architectural features and to reduce the environmental impact of buildings' occupation.

References

Horvat, M., \& Dubois, M. C. (2012). Tools and methods for solar design - An overview of IEA SHC Task 41, Subtask B. Energy Procedia, 30, 11201130. https://doi.org/10.1016/j.egypro.2012.11.125

Jakubiec, J. A., \& Reinhart, C. F. (2011). DIVA 2.0: Integrating daylight and thermal simulations using rhinoceros 3D, DAYSIM and EnergyPlus. In Proceedings of Building Simulation 2011: 12th Conference of International Building Performance Simulation Association (pp. 2202-2209). Sydney, Australia. Retrieved from http://www.scopus.com/inward/record.url?eid=2-s2.0-84870189464\&partnerID=tZOtx3y1

Jerez, J., Cuevas, C., \& Fissore, A. (2016). Experimental validation of SDHW systems and parametric study on their performance based on dwelling characteristics. In proceedings of the 12th REHVA World Congress: volume 3 (paper_340). Aalborg: Aalborg University, Denmark.

Liu, Y.-S., Li, H., Li, H., Pauwels, P., \& Beetz, J. (2015). Recent Advances on Building Information Modeling. The Scientific World Journal, $2015,2-4$. https://doi.org/10.1155/2015/786598

Lobos, D., Wandersleben, G., \& Castillo, L. (2014). Interoperability Map between BIM and BPS Software. Computing in Civil and Building Engineering, (August), 601-608. https://doi.org/10.1061/9780784413616.075

Rahmani, M., Zarrinmehr, S., Bergin, M., \& Yan, W. (2015). BPOpt: A framework for BIM-based performance optimization. Energy and Buildings, 108, 401-412. https://doi.org/10.1016/j.enbuild.2015.09.011

Ministerio de Energía, GEF, PNUD, CDT (2010). Sistemas Solares Tèrmicos II. Guía de diseño e instalación para grandes sistemas de ACS. Chile

Ministerio de Hacienda (2010). Reglamento de la Ley 20.365. Chile.

Senave, M., \& Boeykens, S. (2015). Link between BIM and energy simulation. Building Information Modelling (BIM) in Design, Construction and Operations, 149, 341-352. https://doi.org/10.2495/BIM150291

Shoubi, M. V., Shoubi, M. V., Bagchi, A., \& Barough, A. S. (2015). Reducing the operational energy demand in buildings using building information modeling tools and sustainability approaches. Ain Shams Engineering Journal, 6, 41-55. https://doi.org/10.1016/j.asej.2014.09.006

Wall, M., Windeleff, J., \& Lien, A. (2008). Solar Energy and Architecture: Annex Plan. Solar Heating and Cooling Programe International Energy Agency, (D), 1-16. Retrieved from http://task41.iea-shc.org/data/sites/1/publications/task41-Annex.pdf

Yan, W., Clayton, M., Haberl, J., Jeong, W., Kim, J. B., Texas, A., \& Station, C. (2013). Interfacing BIM with building thermal and daylighting modeling. In Proceedings of Building Simulation 2013: 13th Conference of International Building Performance Simulation Association (pp. 3521-3528). Chambéry, France.

Zalamea, E., \& García, R. (2014). Roof characteristics for integrated solar collection in dwellings of Real- Estate developments in Concepción , Chile. Revista de la Construcción, 13(3), 36-44. 